GRASAS Y ACEITES 68 (1)

January-March 2017, e175

ISSN-L: 0017-3495

doi: http://dx.doi.org/10.3989/gya.0800162

\title{
Effects of microwave roasting on the yield and composition of cold pressed orange seed oils
}

\author{
B. Aydeniz Güneşer and E. Yilmaz \\ Çanakkale Onsekiz Mart University, Faculty of Engineering, Department of Food Engineering, 17020, Çanakkale, Turkey \\ ${ }^{凶}$ Corresponding author: eyilmaz@comu.edu.tr
}

Submitted: 25 July 2016; Accepted: 21 November 2016

SUMMARY: The aim of this study was to valorize orange (Citrus sinensis) seeds, which are generated as waste. This study presents data about raw orange seed, the meal gained after cold pressing, and characterization data of the cold pressed seed oils. Furthermore, the effects of microwave roasting of the seds compared to regular roasting (control) were determined. The oil yield of orange seed cold pressing was around 52.93-62.99\%. After cold pressing, $13.57-17.97 \%$ oil remained in the meal together with $20.68-25.61 \%$ protein. Hence, pressed meals could be valorized for different purposes. Except for turbidity, the color $\mathrm{b}^{*}$ value, free acidity, the $p$-anisidine value and antioxidant capacity, there was no significant difference between the two oil samples for the measured physicochemical properties. Six different fatty acids were quantified and the major fatty acids were linoleic, palmitic and oleic acids. The fatty acid composition of the orange seed oil can be accepted as nutritionally balanced. Among the fifteen sterols quantified, $\beta$-sitosterol was dominant (around 77-78\%). Likewise, the $\alpha$-tocopherol content of the samples was not significantly different. The thermal onset and peak temperatures, and enthalpies for crystallization and melting were also reported. This study showed that good quality orange seed oils can be produced by cold pressing, and the oils could be used in food and non-food applications.

KEYWORDS: Cold pressing; Composition; Oil; Orange seed; Quality; Thermal property

RESUMEN: Efectos del tostado en microondas sobre el rendimiento y la composición de aceites de semillas de naranja prensados en frío. El objetivo de este estudio fue revalorizar las semillas de naranja (Citrus sinensis), que se generan como residuos. Se presentan datos sobre la semilla de naranja cruda, sus harinas obtenidas después del prensado en frío y sobre la caracterización de los aceites de semillas prensadas en frío. Además, se determinaron los efectos del tostado en microondas de las semillas frente al tostado tradicional. El rendimiento del aceite de prensado en frío fue de 52,93-62,99\%. Después de prensado en frío, 13,57-17,97\% del aceite permanece en las harinas junto con 20,68-25,61\% de proteína. Por lo tanto, las harinas de prensa podrían ser revalorizadas para diferentes propósitos. Excepto para turbidez, color b*, acidez libre, p-anisidina y capacidad antioxidante, no hubo diferencia significativa entre los aceites para las propiedades fisicoquímicas medidas. Los ácidos mayoritarios fueron linoleico, palmítico y oleico, en una proporción muy equilibrada nutricionalmente. Entre los quince esteroles cuantificados, el $\beta$-sitosterol fue el predominante (77-78\%). Los contenidos de $\alpha$-tocoferol no fueron significativamente diferente. También se determinó las temperaturas de inicio térmico, picos y las entalpías de cristalización y fusión. Este estudio demostró que los aceites de semillas de naranjas de buena calidad pueden ser producidos por prensado en frío, y los aceites podrían ser utilizados en aplicaciones alimentarias y no alimenticias.

PALABRAS CLAVE: Aceite; Calidad; Composición; Prensado en frío; Propiedades térmicas; Semilla de naranja

ORCID ID: Aydeniz Güneşer B http://orcid.org/0000-0003-2197-5504, Yilmaz E http://orcid.org/0000-0003-1527-5042

Citation/Cómo citar este artículo: Aydeniz Güneşer B, Yilmaz E. 2017. Effects of microwave roasting on the yield and composition of cold pressed orange seed oils. Grasas Aceites 68, e175. http://dx.doi.org/10.3989/gya.0800162

Copyright: (C) 2017 CSIC. This is an open-access article distributed under the terms of the Creative Commons Attribution (CC-by) Spain 3.0 License. 


\section{INTRODUCTION}

The orange (Citrus sinensis L.) is the most abundantly produced fruit among citrus fruits worldwide. It was stated that around 9.7 million ha area were cultivated for citrus fruits, and around 71.5 million tons were produced worldwide in 2013 (Doğan, 2014; Statista, 2016). It was also stated that around $57 \%$ of the total citrus production was oranges. Furthermore, global orange production was about 51 million metric tons, and around 2.1 million metric tons of it was transformed to juice in 2014 (Doğan, 2014; Russo et al., 2015; Matharu et al., 2016). Turkey is situated at number ten in world orange production with 1.779.675 tons of production in 2014. Around 53.800 tons for juice and 2.700 tons for juice concentrate were processed in the same year in Turkey (TUIK, 2014). It is well known that around 3-5\% of the fruit weight comes from seeds (Malacrida et al., 2012), and around 1.500-3.000 tons of orange seeds are generated annualy in Turkey. Since the amount of oranges used for juice production is continually increasing, the amount of seeds generated is increasing steadily. Clearly, orange seeds are an important food supply chain waste generated worldwide to be valorized for sustainable economy and agriculture (Matharu et al., 2016).

There are some studies in the literature reporting the main composition of orange seeds (El-Adawy et al., 1999a, El-Adawy et al., 1999b; Saloua et al., 2009; Russo et al., 2015) in addition to the other components of orange processing waste like pulp and peels. Specifically, some studies exist in the literature indicating the oil content, oil composition and main oil properties of citrus seeds including orange seeds (Abdel-Rahman, 1980; Habib et al., 1986; Lazos and Servos, 1988; El-Adawy et al., 1999a; Saidani et al., 2004; Malacrida et al., 2012; Matthaus and Özcan, 2012). Saidani et al. (2004) have reported around $34 \%$ and $51.8 \%$ oil in blood and sweet orange seeds, respectively. Likewise, around 56.5 and $57.4 \%$ oil has been shown to be present in bitter and sour orange seeds (Matthaus and Özcan, 2012). Furthermore, the fatty acid composition of the bitter and sour orange seeds were given as 9.7 and $11.9 \%$ palmitic, 3.2 and $3.2 \%$ stearic, 23.2 and $19.7 \%$ oleic, 0.6 and $1.0 \%$ vaccenic, 58.3 and $58.9 \%$ linoleic, 2.6 and $0.4 \%$ linolenic and 0.0 and $0.2 \%$ arachidic acids, respectively. The same study reported 17.8 and $17.5 \mathrm{mg} / 100 \mathrm{~g}$ oil total tocopherols with a majority of $\alpha$-tocopherols. In addition, 2038.1 and $2506.6 \mathrm{mg} / \mathrm{kg}$ total sterols with a majority of $\beta$-sitosterol, campesterol and $\Delta 5$-avenasterol were reported (Matthaus and Özcan, 2012). Another study (Saloua et al., 2009) reported orange seed oil properties in more detail. The reported physicochemical properties were: the saponification number of 174.57 ; the iodine value of $141.43 \mathrm{~g}$ $\mathrm{I} / 100 \mathrm{~g}$ oil; the $p$-anisidine value of 1.86 ; the peroxide value of $2.33 \mathrm{meqO}_{2} / \mathrm{kg}$; the acid value of $0.66 \mathrm{mg}$
$\mathrm{KOH} / \mathrm{g}$ oil; the carotenoid content of $0.59 \mathrm{mg} / 100 \mathrm{~g}$ oil; the chlorophyll content of $0.02 \mathrm{mg} / 100 \mathrm{~g}$ oil and the refractive index of 1.45. Also the fatty acid composition was linoleic $(76.19 \%)$, oleic $(13.87 \%)$, stearic $(6.76 \%)$ and palmitic acid $(2.40 \%)$. Furthermore, the sterol contents of $852.93 \mathrm{mg} / 100 \mathrm{~g}$ seed oil with $81 \%$ sitosterol; and 18.92, 10.8, 6.02, and $6.29 \mathrm{mg} / 100 \mathrm{~g}$ of $\alpha-, \gamma-, \beta$-, and $\delta$-tocopherols were quantified. These studies clearly pointed out that orange seeds could be a feasible source for oil production, and the oil could be used in various applications like food, chemicals, fuel, cosmetics, and pharmaceuticals.

However, none of the studies focused on the utilization and yield of oil production from orange seeds. Hence, we aimed in this study to present the possibility of gaining oil from orange seeds by cold pressing. Since cold pressing is a unique process applied to various oil bearing seeds and kernels to produce specialty oils with distinguished aroma and nutritional composition but with relatively low yield (Aydeniz et al., 2014; Yilmaz et al., 2015a), we selected cold pressing to get orange seed oil and to characterize the produced oil. After all, cold presses could easily be constructed as simple production lines in or near orange juice facilities to valorize the orange seed waste. Moreover, cold pressed oils do not require refining processes, and they are free from chemical contaminants and impurities.

Since oil yield is usually lower in cold pressing compared to solvent extraction (Khoddami et al., 2014; Aydeniz et al., 2014; Y1lmaz et al., 2015a), some pre-treatments like de-hulling, steaming, enzyme applications, heating, microwave application, etc., are applied to the seeds to enhance oil yield (Williams and Hron, 1996; Aydeniz et al., 2014). For example, Azadmard-Damirchi et al. (2010) applied microwave to canola seeds before cold pressing, and showed that oil yield increased, and oil phytosterol, tocopherol and oxidative stability were enhanced. In another study (Aydeniz et al., 2014), microwave treatments on safflower seeds prior to cold pressing showed oils with a lower turbidity value, free acidity and $\alpha$-tocopherol contents, but total phenolics, antioxidant capacity and the nutty aroma of the oils were enhanced. Cold pressing yields oils which do not need refining processes, and retain most of the minor or bioactive components naturally present. Hence, cold pressed oils usually have special applications in food enrichments, health-related areas and cosmetic sectors. In this study we intend to compare seed microwave treatment prior to cold pressing to observe how oil yield and oil properties changed.

The objectives of this study were to show the possibility of oil production from orange seeds using the cold pressing technique, as well as to compare the effects of microwave roasting and conventional roasting on oil yield and composition. Furthermore, some properties (cold press meal composition and oil thermal properties) of the cold pressed orange seed 
oils and meal were reported for the first time in the literature in addition to the main physicochemical and compositional (fatty acid, sterol and tocopherol) data obtained and compared for the cold-press produced oils. We expect that the results of this study may encourage some industrial scale actions to produce cold pressed orange seed oils for different applications.

\section{MATERIALS AND METHODS}

\subsection{Materials}

Seeds from the oranges of the Dörtyol variety (Citrus sinensis L. Osbeck) were provided by the Anadolu Etap Penkon Co. Inc. (Mersin, Turkey) from the 2013-2014 processing season. Around $50 \mathrm{~kg}$ of washed and dried seeds were kept in a deepfreezer $\left(-20{ }^{\circ} \mathrm{C}\right)$ until cold pressing. All chemicals used were of analytical grade and purchased from Merck Co. (Darmstadt, Germany) and Sigma Chem. Co. (St. Louis, USA). Fatty acid, tocopherol and sterol standards were purchased from Supelco (Bellefonte, PA, USA), Nu-Check (Elysian, MN, USA) and Sigma Chem. Co.

\subsection{Seed analyses}

The seed dimensions were measured by a digital caliper (CD-15CP, Mitutoyo Ltd., Andover, UK) on 100 randomly selected seeds. Similarly, to determine the 1000-seed weight, 10 randomly selected seeds were weighed (Sartorius ED224S, Sartorius, Germany), and multiplied by 100 . Both measurements were repeated four times. The skin: flesh ratio was determined by removing the seed coats and weighing skin and flesh separately from 10 seeds, four times. A Minolta colorimeter (CR-400, Osaka, Japan) calibrated previously against white tile was used to read the seed color. Ohaus MB45 moisture analyzer (Ohaus, Switzerland) and AquaLab 4TE (Decagon Inc. USA) were used to measure the moisture content $(\%)$ and water activity $\left(\mathrm{a}_{\mathrm{w}}\right)$ values of the orange seeds, respectively. Similarly, seed oil content using method 920.39 (AOAC, 2005); seed protein using the Kjeldahl method of Aa 5-38 (AOCS, 1997), and seed total ash using the Ba 5a-49 method (AOCS, 1997) were measured.

\subsection{Seed preparation and cold pressing}

The control group (regular seed roasting) was prepared by heating seeds for $30 \mathrm{~min}$ at $150{ }^{\circ} \mathrm{C}$ in an oven (Inoksan FPE 110, Bursa, Turkey) with frequent agitation. The treatment group (microwave roasting) was achieved by heating seeds at 360 Watt for a total of $30 \mathrm{~min}$, applying a 3-min pause mode of action every three minutes. Then, the seed moisture level was determined and adjusted to $11 \%$ by water conditioning (Aydeniz et al., 2014) before cold pressing. A laboratory scale cold-press machine (single head, $2 \mathrm{hp}, 1.5 \mathrm{~kW}$ power, $12 \mathrm{~kg}$ seed/h capacity, Koçmaksan, ESM 3710, İzmir, Turkey) was used to cold press the orange seeds. The operation conditions were $30 \mathrm{rpm}$ screw rotation speed, $10 \mathrm{~mm}$ exit die and $40{ }^{\circ} \mathrm{C}$ maximum oil exit temperature. The cold pressings were repeated twice for each treatment group. The cold pressed oils were first centrifuged (Sigma 2-16 K, Postfach, Germany) at $6797 \mathrm{xg}$ for $10 \mathrm{~min}$, then placed in amber-colored glasses and flushed with nitrogen before capping. Until and during the analyses, the oil samples were kept in the fridge. The press meal exiting the cold press machine was first ground (Retch Grindomix GM 300, Germany), and then placed in refrigerator bags and kept at $-20^{\circ} \mathrm{C}$ until analysis.

\subsection{Composition of press meals}

The orange seeds and press meal gained after cold pressing can be observed in Figure. 1. The proximate composition (moisture, ash, remaining oil,

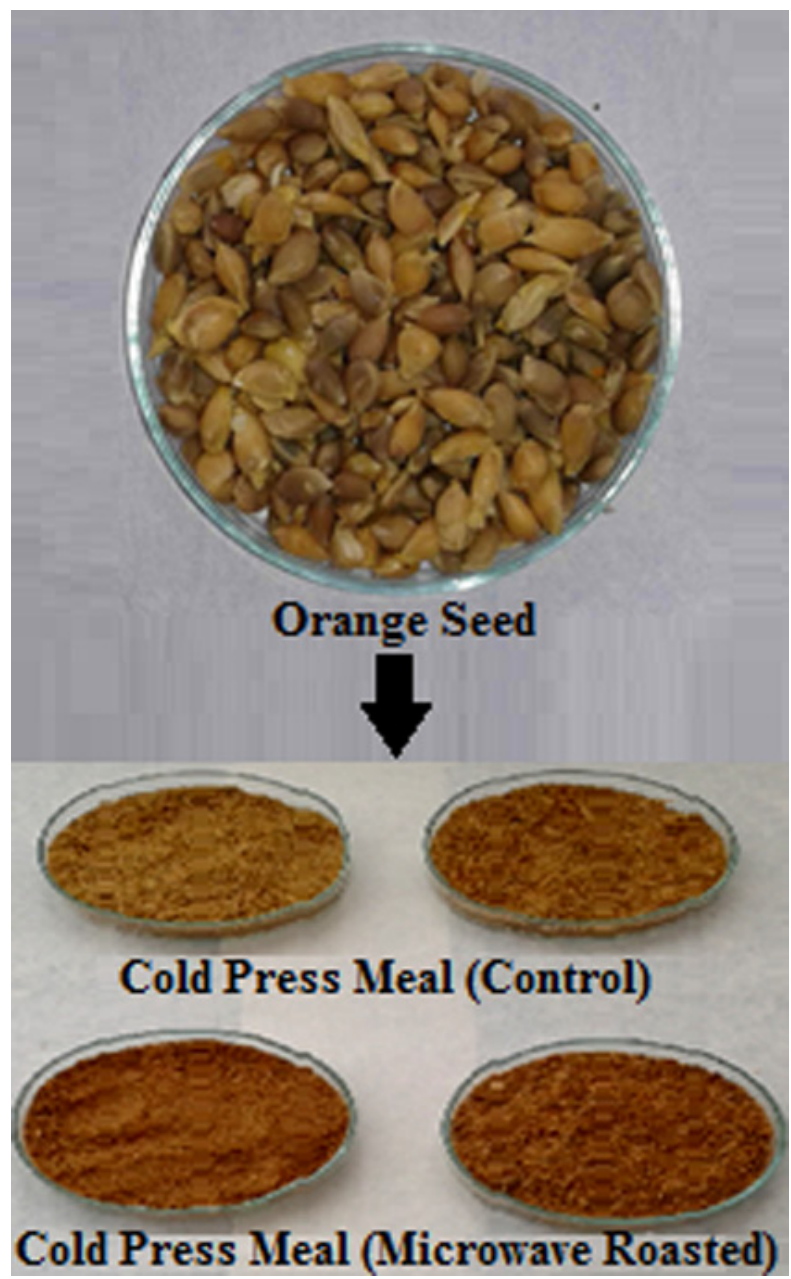

FIgURE 1. The orange seeds and the meals gained after cold pressing of the seeds. 
and protein contents) and color were measured with the same methods described above for the seeds. The press meal was then deep-frozen for further studies.

\subsection{Oil physicochemical properties}

The specific gravity of the oil was measured by the AOCS Cc 10c-95 method (AOCS, 1997) at $25{ }^{\circ} \mathrm{C}$. The Abbe 5 (Bellingham and Stanley, UK) refractometer was used $\left(25^{\circ} \mathrm{C}\right)$ to read the refractive indices of the oil samples. Apparent oil viscosities were measured at $25^{\circ} \mathrm{C}$ with the Brookfield Viscometer (model DV II+Pro with Rheocalc software, Brookfield Eng. Lab., Inc., MA, USA) and a no:18 spindle rotating at $30 \mathrm{rpm}$. The oil turbidities were measured at $25^{\circ} \mathrm{C}$ with a Hach $2100 \mathrm{AN}$ Turbidimeter (USA). Instrumental colors were read with a Minolta Colormeter CR-400 (Minolta Camera Co., Osaka, Japan). The oil sediment contents were assessed gravimetrically (Dündar Emir et al., 2015). The free fatty acidity and acid values of the oil samples were measured by $\mathrm{Ca} 5 \mathrm{a}-40$ and Cd 3d-63 methods (AOCS, 1997). Likewise, peroxide value, $p$-anisidine value and iodine number were measured according to the methods $\mathrm{Cd} \mathrm{8-53,} \mathrm{Cd}$ 18-90, and Cd 1-25 (AOCS, 1997), respectively. The saponification numbers were determined according to T1 1a-64 (AOCS, 1997) and unsaponifiable matter following ISO 3596 (ISO, 2000) methods. Total phenolic contents were measured according to the FolinCiocalteu reagent technique, and the antioxidant capacities of the phenolic extracts were measured by the Trolox equivalent antioxidant capacity (TEAC) technique according to Aydeniz and Yilmaz (2012).

\subsection{Fatty acid, sterol and tocopherol compositions}

The fatty acid analysis of the orange seed oils was completed by preparation of the methyl esters $(\mathrm{Ce}$ 2-66 method, AOCS, 1997) and quantification by a Gas Chromatograph (Agilent Technologies 7890B, Palo Alto, CA, USA) equipped with a flame ionization detector (FID) (Agilent Technologies, Palo Alto, CA, USA), and HP 88 capillary column $(100 \mathrm{~m} \times 0.25 \mathrm{~mm}$ ID $\times 0.2 \mu \mathrm{m}$ film thickness, J\&W Scientific Co, CA, USA). Conditions of the analysis were; oven temperature: $120{ }^{\circ} \mathrm{C}$ for $1 \mathrm{~min}$, $175^{\circ} \mathrm{C}\left(10^{\circ} \mathrm{C} / \mathrm{min}\right)$ for $10 \mathrm{~min}, 210^{\circ} \mathrm{C}\left(5^{\circ} \mathrm{C} / \mathrm{min}\right)$ for $5 \mathrm{~min}$ and $230{ }^{\circ} \mathrm{C}\left(5^{\circ} \mathrm{C} / \mathrm{min}\right)$ for $5 \mathrm{~min} ; 1 \mu \mathrm{L}$ injection volume, 1:50 injector split ratio, $2 \mathrm{ml} / \mathrm{min}$ flow rate. The carrier gas was hydrogen and the temperatures of the injector and detector were 250 and $280{ }^{\circ} \mathrm{C}$, respectively. Fatty acid quantification was achieved with co-chromatography of the FAME standard mixture (37-components, C4-C24, Supelco, Bellefonte, PA, USA).

The sterol composition of oil samples was determined by the ISO 12228 method (ISO, 1999). The sterol fraction of the oils was first separated on
TLC after saponification. Then the sterols were analyzed with a Gas Chromatograph-FID (Agilent Technologies 7890B, Palo Alto, CA, USA) and DB5 capillary column $(30 \mathrm{~m} \times 0.25 \mathrm{~mm}$ ID $\times 0.1 \mu \mathrm{m}$ film thickness, J \&W Scientific Co, CA, USA). The oven temperature and thermal programming were $60{ }^{\circ} \mathrm{C}$ for $2 \mathrm{~min}, 60-220^{\circ} \mathrm{C}\left(40{ }^{\circ} \mathrm{C} / \mathrm{min}\right)$ for $1 \mathrm{~min}$, $220-310^{\circ} \mathrm{C}\left(5^{\circ} \mathrm{C} / \mathrm{min}\right)$ for $30 \mathrm{~min}$. The injection volume was $1 \mu \mathrm{L}$, with a $1: 100$ injector split ratio, $0.8 \mathrm{ml} / \mathrm{min}$ flow rate, $30 \mathrm{ml} / \mathrm{min}$ hydrogen carrier gas flow, and 290 and $300{ }^{\circ} \mathrm{C}$ injector and detector temperatures, respectively. The relative retention times of available standards (cholesterol, brassicasterol, stigmasterol, $\beta$-sitosterol) were used for sample identification and quantification.

The amount of $\alpha$-tocopherol was determined with reverse-phase HPLC (Shimadzu Corporation, Kyoto, Japan) equipped with a LC-20AT HPLC pump, DGU-20A5R degasser, CTQ-10ASVP column oven, and RF-20A diode array detector. The method of Grilo Câmara et al. (2014) was followed with minor modifications. Each of the $0.15 \mathrm{~g}$ oil samples was dissolved in $3 \mathrm{ml}$ dichloromethane, and from this stock around $20 \mu \mathrm{l}$ of sample were injected into the Inertsil ODS-3 column $(250 \mathrm{~mm} x$ $4.6 \mathrm{~mm}$ x $5 \mu \mathrm{m}$, GL Sciences Inc., Japan) by an autosampler (SIL-20AHT). The methanol: water $(98: 2 \mathrm{v} / \mathrm{v})$ mobile phase was eluted with a $1.6 \mathrm{ml} / \mathrm{min}$ isocratic flow rate. The detector excitation and emission wavelengths were $290 \mathrm{~nm}$ and $330 \mathrm{~nm}$. The $\alpha$-tocopherol standard was used for quantification (Merck, Darmstadt, Germany).

\subsection{Thermal analysis}

The melting and crystallization temperatures, and enthalpies of the orange seed oil samples were assessed by a Perkin-Elmer 4000 Series Differential Scanning Calorimeter (Groningen, The Netherlands). The previously calibrated (with Indium and Zinc) instrument was purged with nitrogen at a $50 \mathrm{ml} / \mathrm{min}$ flow for half an hour to clean the sample holder. Then around 5-10 mg oil sample were weighed and sealed hermetically in aluminum pans, and put in the instrument. The temperature program applied was heating from room temperature to $110{ }^{\circ} \mathrm{C}$ by $10{ }^{\circ} \mathrm{C} / \mathrm{min}$ then cooling to $-70{ }^{\circ} \mathrm{C}$ by $10{ }^{\circ} \mathrm{C} / \mathrm{min}$ and holding at that temperature for $3 \mathrm{~min}$ for full crystallization, and finally heating to $50{ }^{\circ} \mathrm{C}$ by $5^{\circ} \mathrm{C} / \mathrm{min}$. The thermograms were used to calculate the parameters with the Pyris 1 Manager software (Yilmaz et al., 2015b).

The oxidative induction time (OIT) was also measured with the DSC. Samples were prepared as previously indicated and exposed to heating from $30{ }^{\circ} \mathrm{C}$ to $130{ }^{\circ} \mathrm{C}$ at $20{ }^{\circ} \mathrm{C} / \mathrm{min}$ under constant $50 \mathrm{ml} / \mathrm{min}$ nitrogen flushing. Then an isothermal temperature programming at $130{ }^{\circ} \mathrm{C}$ with $50 \mathrm{ml} / \mathrm{min}$ purified oxygen $(99.8 \%)$ was applied to the samples until curve 
departure for OIT calculation. The Pyris 1 Manager software was used to calculate the OIT values (Yilmaz et al., 2015b).

\subsection{Statistical analyses}

Oil production from the orange seeds by the cold pressing technique were repeated twice, and for each oil sample produced, the analyses were conducted at least in duplicate or in triplicate. Comparisons of the treatments were completed by one-way ANOVA and Tukey's tests by Minitab ver. 16.1.1 (Minitab, 2010) and SPSS package (SPSS, 1994) statistics programs. There was a 95\% minimum confidence level for all statistical analyses.

\section{RESULTS AND DISCUSSION}

\subsection{Properties of the orange seed and press meal}

The main physicochemical properties of the orange seeds used in this study (Figure. 1) are presented in Table 1. These are the raw material properties before the seeds were cold pressed. Seed dimensions, 1000-seed weight, skin: flesh ratio and seed color could depend on the seed variety as well as agricultural practices. These data are just to define the material used in this study. There is no similar data in the literature to compare. The seed moisture content and water activity at the beginning were determined, but before cold pressing, the moisture content of the seeds was arranged to $11 \%$ by water conditioning, as explained. The orange seeds used in this study included around $40.75 \%$ oil, $19.22 \%$ protein and $1.58 \%$ ash. In an early study (Habib et al., 1986), orange seeds were shown to contain $17.40 \%$ protein, $45.46 \%$ lipid, $34.13 \%$ carbohydrate and $2.95 \%$ ash. Similarly, El-Adawy et al. (1999a) reported the protein, crude lipid and ash contents of raw orange seed as $17.01,42.59$, and $3.12 \%$, respectively. Our results concur with theirs. In another study (Anwar et al., 2008), four different citrus species, mitha (Citrus limetta), grapefruit (Citrus paradisi), mussami (Citrus sinensis), and kinnow (Citrus reticulata) were investigated. They indicated $27.00-36.54 \%$ oil, 3.90-9.51\% protein and $4.60-5.60 \%$ ash in the samples. Differences with our samples could be due to seed variety. In a more recent study (Saloua et al., 2009), $33.89 \%$ protein, $32.75 \%$ oil, $20.76 \%$ carbohydrate and $6.72 \%$ ash were reported for orange seeds. The proximate composition data in this study is in accordance with the literature.

After cold pressing of the orange seeds, the press meal (cake) was collected and analyzed (Table 2). There were some differences between the two treatment groups (regularly roasted and cold-pressed control sample and microwave roasted and coldpressed sample) for water activity, oil and protein content, and color a* values. Obviously, the oil remaining in the meal was significantly higher in the control sample, while for the protein the contrary result was seen. Clearly, microwave roasted seeds infiltrated their oil with higher yields during pressing. A higher percentage of protein was

TABLE 1. Material properties of orange seeds

\begin{tabular}{lclc}
\hline Property & Mean \pm SD & Property & Mean \pm SD \\
\hline Seed size $(\mathrm{mm})$ & & Color a & $2.42 \pm 0.45$ \\
Length & $11.69 \pm 0.49$ & Color b* & $17.47 \pm 1.71$ \\
Width & $5.06 \pm 0.13$ & Moisture $(\%)$ & $43.99 \pm 0.13$ \\
1000-Seed weight $(\mathrm{g})$ & $197.21 \pm 2.90$ & Water activity $\left(25^{\circ} \mathrm{C}\right)$ & $0.96 \pm 0.01$ \\
Skin: Flesh ratio (w/w) & $0.29 \pm 0.02$ & Oil $^{\dagger}(\%)$ & $40.75 \pm 2.17$ \\
Color L & $49.33 \pm 3.17$ & Protein $^{\dagger}(\%)$ & $19.22 \pm 0.09$ \\
& & Ash $(\%)$ & $1.58 \pm 0.01$ \\
\hline
\end{tabular}

${ }^{\dagger}$ Values are on dry weight basis.

TABle 2. Proximate composition of the meal from cold-pressed orange seeds

\begin{tabular}{lcclcc}
\hline & \multicolumn{5}{c}{ Orange Seed Meal } \\
\cline { 2 - 6 } Property & \multicolumn{1}{c}{ Control } & Microwaved Roasted & Property & \multicolumn{1}{c}{ Control } & Microwaved Roasted \\
\hline Moisture $(\%)$ & $11.11 \pm 0.09^{\mathrm{A}}$ & $9.72 \pm 1.46^{\mathrm{A}}$ & Protein $^{\dagger}(\%)$ & $20.68 \pm 0.29^{\mathrm{B}}$ & $25.61 \pm 1.08^{\mathrm{A}}$ \\
Water activity $\left(25^{\circ} \mathrm{C}\right)$ & $0.71 \pm 0.01^{\mathrm{A}}$ & $0.65 \pm 0.06^{\mathrm{B}}$ & Color L & $54.14 \pm 0.99^{\mathrm{A}}$ & $51.82 \pm 0.24^{\mathrm{A}}$ \\
Ash $(\%)$ & $4.19 \pm 0.09^{\mathrm{A}}$ & $4.41 \pm 0.03^{\mathrm{A}}$ & Color a $^{*}$ & $6.20 \pm 0.47^{\mathrm{B}}$ & $8.60 \pm 0.28^{\mathrm{A}}$ \\
Oil $^{\dagger}(\%)$ & $17.97 \pm 0.58^{\mathrm{A}}$ & $13.57 \pm 0.74^{\mathrm{B}}$ & Color b $^{*}$ & $22.27 \pm 0.73^{\mathrm{A}}$ & $22.48 \pm 0.46^{\mathrm{A}}$ \\
\hline
\end{tabular}

${ }^{\dagger}$ Values are on dry weight basis.

A,B means in the same horizontal rows followed by different superscript letters were significantlydifferent $(p<0.05)$. 
observed in the group treated with microwave, an expected result because decreasing of the percentincrease in the other components. Higher $a^{*}$ values in the microwave roasted meal means a more reddish color, as can be observed from Figure. 1. Clearly the color values of the seeds (Table 1) and meal (Table 2) are fairly different, since after pressing the wholesomeness of the material is lost meal data show that this material can be valorized for different purposes, since it includes substantial amounts of protein and remaining oil.

\subsection{Physicochemical properties of the orange seed oils}

Common physicochemical properties, total phenolic contents and antioxidant capacity values of the two cold pressed orange seed oils are presented in Table 3. The oil yield values calculated over the total oil content of the seeds indicate that seed microwave treatment enhanced cold-press oil yield significantly $(62.99 \%$ versus $52.93 \%$ in the control sample). Oil yield is an important parameter in terms of economic gain in cold pressing, but oil properties would also be very important in terms of oil quality. There were no differences in specific gravity, refractive index or viscosity values for the two samples, while oil turbidities were significantly different. Seed microwave treatment caused the oil to be more turbid. While the color parameters, $\mathrm{L}$ and $\mathrm{b}^{*}$ values were not different, the $\mathrm{a}^{*}$ value was higher in the microwave treated sample. This means that the microwave treated sample is a little more reddish. Around 6.65-7.57\% sediment content was found in the oil sample with no difference between the treatments. The density of four species of citrus seed oils were reported as 0.920-0.941 (Anwar et al., 2008). El-Adawy et al. (1999a) reported a refractive index of 1.4684 , a density of 0.914 and viscosity of $0.007 \mathrm{~Pa}$.s for orange seed oil. Our findings concur with the literature.

For both oil samples, there were no significant differences for acid value, peroxide value, iodine or saponification numbers, or unsaponifiable matters (Table 3 ). The free fatty acidity of the control sample $(0.27 \%)$ was significantly lower than that of the microwave treated sample $(0.34 \%)$, and both samples had fairly low acid values $(0.54$ and $0.69 \mathrm{mg} \mathrm{KOH} / \mathrm{g}$ oil). Both oils could be fairly acceptable, since the Turkish codex for named vegetable oils (Codex, 2012) permits up to $4.0 \mathrm{mg} \mathrm{KOH} / \mathrm{g}$ oil acid value for cold-pressed and virgin oils. In one study (Habib et al., 1986), the acid values of $0.21,0.65,1.20$, and $0.90 \mathrm{mg} \mathrm{KOH} / \mathrm{g}$ oil were published for orange, mandarin, lime and grapefruit seed oils, respectively. Likewise, acid values ranging from 0.673 to $1.120 \mathrm{mg} \mathrm{KOH} / \mathrm{g}$ oil were reported for four other citrus seed oils (El-Adawy et al., 1999a). Our data generally concur. The peroxide values (PV) age of one of the components (oil) will generate an and some color reactions may occur. Orange seed

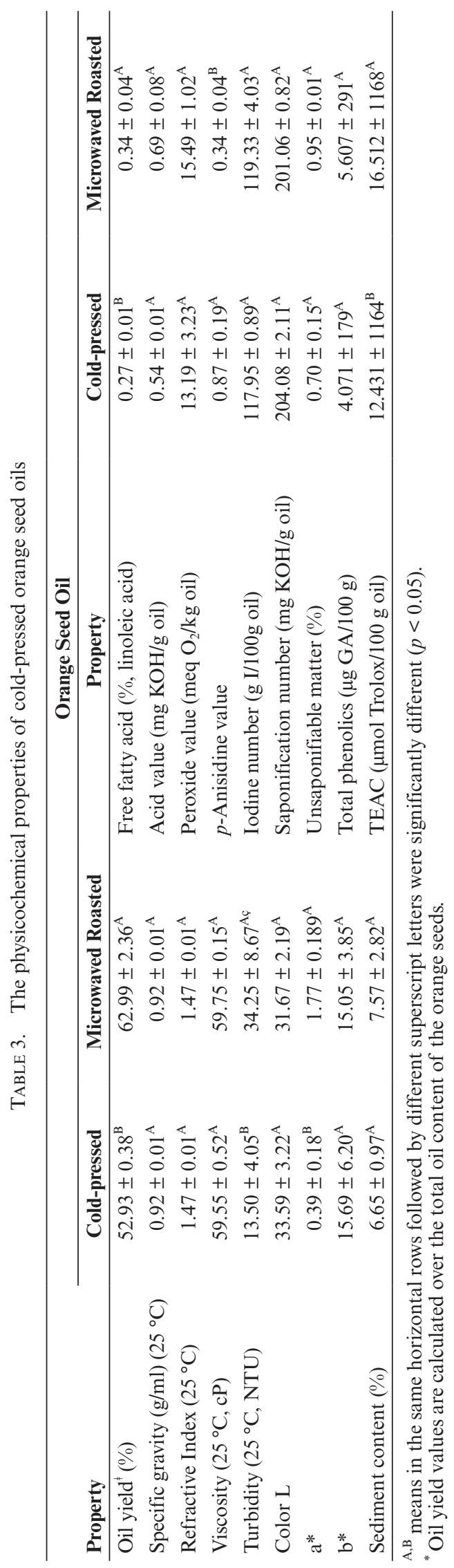

Grasas Aceites 68 (1), January-March 2017, e175. ISSN-L: 0017-3495 doi: http://dx.doi.org/10.3989/gya.0800162 
and $p$-anisidine values $(p-\mathrm{AV})$ of the oils indicate the oxidation status of samples. The codex (Codex, 2012) permits a maximum of $15 \mathrm{meq} \mathrm{O}_{2} / \mathrm{kg}$ oil peroxide value for virgin oils. Hence, the microwave treated sample exceeds this limit by a little ( 15.49 meq $\mathrm{O}_{2} / \mathrm{kg}$ oil), and might require further treatment. Clearly, seed microwave roasting enhances the PV compared to regular roasting. The PV of $6.37 \mathrm{meq} \mathrm{O}_{2} / \mathrm{kg}$ oil (El-Adawy et al., 1999a), and PV of 2.33 meq $\mathrm{O}_{2} / \mathrm{kg}$ oil and $p-\mathrm{AV}$ of 1.86 (Saloua et al., 2009) were reported for orange seed oils. Clearly the reported values are significantly lower than our samples, but it must also be pointed out that in our study we cold pressed the seed oils at laboratory pilot scale production rather than laboratory scale solvent extraction. It was stated that the oxidation status of an oil would depend on its chemical nature as well as its production, processing and storage conditions, and age (O'Brien, 2003). In our previous study (Aydeniz et al., 2014), the PVs of regularly roasted safflower seed oil (3.85 meq $\mathrm{O}_{2} / \mathrm{kg}$ oil) was found significantly lower than that of the microwave treated counter sample $\left(9.40 \mathrm{meq} \mathrm{O}_{2} / \mathrm{kg}\right.$ oil $)$, and this finding agrees with the measured PVs in this study. Although seed pre-treatment with microwave could enhance oil yield, it also causes the PV to increase.

There were no significant differences in the orange seed oils for the iodine and saponification numbers, or unsaponifiable matter contents. The iodine and saponification numbers for the control and microwave treated oil samples ranged between 117.95-119.33 g $\mathrm{I} / 100 \mathrm{~g}$ oil, and $204.08-201.06 \mathrm{mg} \mathrm{KOH} / \mathrm{g}$ oil, respectively. El-Adawy et al. (1999a) reported $102.57 \mathrm{~g} \mathrm{I} / 100 \mathrm{~g}$ oil as the iodine number, and $190.2 \mathrm{mg} \mathrm{KOH} / \mathrm{g}$ oil as the saponification number for orange seed oil. In another study, Anwar et al., (2008) reported iodine values ranging (g I/100 g oil) from 99.85-110.00; saponification number (mg KOH/g oil) from 180.90-198.85; unsaponifiable matter $(\%)$ from $0.31-0.50$ for four different citrus species. Saloua et al. (2009) reported iodine and saponification numbers and unsaponifiable matter with the same units as 141.43, 174.57, and 1.57 for orange seed oil, respectively. Obviously, our iodine and saponification numbers were a little higher than those reported in the literature.

While the total phenolic contents (4071 and $5607 \mu \mathrm{g} \mathrm{GA} / 100 \mathrm{~g}$ oil) of the two oil samples were not statistically different, their antioxidant capacity values (12431 and $16512 \mu \mathrm{mol}$ Trolox/100 g oil) were statistically significantly different. Moreover, it is clear that the antioxidant capacity/phenolic content (ac/pc) ratios of both seed oils (3.053 and 2.944) were not very different. The total phenolic content (as $\mu \mathrm{g}$ GAE/100 g oil) of orange seed oil was reported as 115288 (Malacrida et al., 2012). This value is significantly higher than we measured in our samples. Furthermore, Malacrida et al. (2012) reported 47.6\% quenching ability for the DPPH radical of orange seed oil, and indicated that the highest antioxidant capacity was in orange seed oil compared with lemon and tangerine seed oils. Unfortunately, there is no other data available in the literature to compare with our findings. We reported (Aydeniz et al., 2014) 2855.70 and $4079.30 \mu \mathrm{g} \mathrm{GA} / 100 \mathrm{~g}$ oil for total phenolics, and 315.32 and $538.26 \mu \mathrm{mol}$ Trolox/g oil for the antioxidant capacity of regularly roasted and microwave roasted safflower seed oil samples. Clearly, cold-pressed orange seed oils are very high phenoliccontaining and high antioxidant capacity-exhibiting samples. Hence, this oil could be added to other oils or foods as antioxidant and/or phenolic containing supplements.

\subsection{Component compositions of the orange seed oils}

The fatty acid, sterol and $\alpha$-tocopherol contents of the orange seed oil samples are summarized in Table 4. There was no difference between

TABLE 4. Fatty acid, sterol and tocopherol compositions of the cold pressed orange seed oils

\begin{tabular}{|c|c|c|}
\hline & \multicolumn{2}{|c|}{ Orange Seed Oil } \\
\hline & Control & $\begin{array}{l}\text { Microwaved } \\
\text { Roasted }\end{array}$ \\
\hline \multicolumn{3}{|l|}{ Fatty acids (\%) } \\
\hline Palmitic (C16:0) & $25.71 \pm 0.23^{\mathrm{A}}$ & $26.10 \pm 0.08^{\mathrm{A}}$ \\
\hline Palmitoleic (C16:1) & $0.52 \pm 0.01^{\mathrm{A}}$ & $0.52 \pm 0.01^{\mathrm{A}}$ \\
\hline Stearic (C18:0) & $5.75 \pm 0.11^{\mathrm{A}}$ & $5.87 \pm 0.03^{\mathrm{A}}$ \\
\hline Oleic (C18:1 n-9) & $25.33 \pm 0.12^{\mathrm{A}}$ & $24.81 \pm 0.06^{\mathrm{A}}$ \\
\hline Linoleic (C18:2 n-6) & $36.59 \pm 0.17^{\mathrm{A}}$ & $36.61 \pm 0.05^{\mathrm{A}}$ \\
\hline Linolenic (C18:3 n-3) & $4.14 \pm 0.02^{\mathrm{A}}$ & $4.19 \pm 0.01^{\mathrm{A}}$ \\
\hline \multicolumn{3}{|l|}{ Sterols (\%) } \\
\hline Cholesterol & $0.66 \pm 0.03^{\mathrm{A}}$ & $0.77 \pm 0.06^{\mathrm{A}}$ \\
\hline Brassicasterol & $0.07 \pm 0.02^{\mathrm{B}}$ & $0.49 \pm 0.32^{\mathrm{A}}$ \\
\hline 24-methylen cholesterol & $0.05 \pm 0.01^{\mathrm{B}}$ & $0.18 \pm 0.07^{\mathrm{A}}$ \\
\hline Campesterol & $9.43 \pm 0.12^{\mathrm{A}}$ & $9.97 \pm 0.17^{\mathrm{A}}$ \\
\hline Campestanol & $0.21 \pm 0.04^{\mathrm{A}}$ & $0.26 \pm 0.08^{\mathrm{A}}$ \\
\hline Stigmasterol & $3.26 \pm 0.15^{\mathrm{A}}$ & $3.47 \pm 0.06^{\mathrm{A}}$ \\
\hline$\Delta-7$ campesterol & $0.29 \pm 0.02^{\mathrm{B}}$ & $0.65 \pm 0.02^{\mathrm{A}}$ \\
\hline$\Delta-5,23$ stigmastadienol & nd & $0.19 \pm 0.07$ \\
\hline Chlerosterol & $1.16 \pm 0.05^{\mathrm{A}}$ & $0.83 \pm 0.15^{\mathrm{B}}$ \\
\hline Beta-sitosterol & $78.72 \pm 0.91^{\mathrm{A}}$ & $77.65 \pm 1.49^{\mathrm{A}}$ \\
\hline Sitostanol & $0.62 \pm 0.10^{\mathrm{B}}$ & $2.32 \pm 0.99^{\mathrm{A}}$ \\
\hline$\Delta-5$ avenasterol & $4.59 \pm 0.05^{\mathrm{A}}$ & $1.52 \pm 0.93^{\mathrm{B}}$ \\
\hline$\Delta-5,24$ stigmastadienol & $0.17 \pm 0.06^{\mathrm{B}}$ & $0.74 \pm 0.37^{\mathrm{A}}$ \\
\hline$\Delta-7$ stigmastenol & $0.51 \pm 0.11^{\mathrm{B}}$ & $0.77 \pm 0.23^{\mathrm{A}}$ \\
\hline$\Delta-7$ avenasterol & $0.26 \pm 0.12^{\mathrm{A}}$ & $0.18 \pm 0.07^{\mathrm{B}}$ \\
\hline Tocopherol (mg/kg oil) & & \\
\hline$\alpha$-Tocopherol & $283.40 \pm 24.60^{\mathrm{A}}$ & $256.65 \pm 8.21^{\mathrm{A}}$ \\
\hline
\end{tabular}

A-B means in the same horizontal rows followed by different superscript letters were significantly different $(p<0.05)$. nd: not detected. 
the control and microwave roasted samples for the fatty acid composition. Six fatty acids were quantified, and the most abundant ones were linoleic acid (around 36\%), palmitic acid (around $26 \%$ ) and oleic acid (around 25\%). The amounts of linolenic and palmitoleic acids were around $4 \%$ and $0.5 \%$, respectively. There are similar but differently ranged numbers in the literature for different orange seed varieties. Saidani et al. (2004) reported $34.40 \%$ palmitic, $3.40 \%$ stearic, $14.90 \%$ oleic, $40.30 \%$ linoleic and $4.0 \%$ linolenic acids, as the major fatty acids for sweet orange seeds. Clearly the amounts of oleic and linolenic acid are fairly different from ours. Matthaus and Ozcan (2012) reported the fatty acid composition of orange seeds originating from Turkey as $26.6 \%$ palmitic, $4.9 \%$ stearic, $22.4 \%$ oleic, $1.3 \%$ vaccenic, $39.9 \%$ linoleic, $3.7 \%$ linolenic and $0.4 \%$ arachidic acids. Likewise, Malacrida et al. (2012) gave a very similar fatty acid composition data for orange seed oils. Hence, our data mostly concur with the data of Matthaus and Özcan (2012) and Malacrida et al. (2012).

The sterol composition (\%) of the orange seed oil samples is also presented in Table 4. There were fifteen different sterols with the highest ratios of $\beta$-sitosterol (around 78\%), campesterol (around 9-10\%), stigmasterol (around $3-3.5 \%$ ) and $\Delta-5$-avenasterol (around 1.5-5\%). Furthermore, cholesterol, brassicasterol, 24-methylene cholesterol, campestanol, $\Delta$-7-campesterol, $\Delta$-5,23-stigmastadienol, chlerosterol, sitostanol, $\Delta$-5,24-stigmastadienol, $\Delta$-7-stigmastenol and $\Delta$-7-avenasterol were quantified at less than $1.0 \%$ concentrations. Most sterols were not different between the the two samples, while some small differences existed for only several small quantity sterols between the two samples (Table 4). Clearly, seed pre-treatment had no extensive effect on sterol composition other than some small but statistically significant differences. In one study (Saloua et al., 2009), the sterol composition of orange seed oil was reported as around $81 \% \beta$-sitosterol, 7.4\% campesterol, $4.2 \%$ stigmasterol, $4.1 \%$ lupeol and $3.2 \% \Delta$-5-avenasterol. These values turn out to be very similar to ours, except for lupeol, which we have not quantified. Matthaus and Özcan (2012) reported the major sterol composition of orange seed oil as $77.9 \% \beta$-sitosterol, $8.0 \%$ campesterol, $4.3 \%$ stigmasterol and $4.1 \% \Delta-5$-avenesterol and others. This data is also concurring with our findings. Hence it could be said that seed pre-treatments had no effect on sterol composition, and the sterol composition data are in good agreement with existing literature.

We have quantified only the $\alpha$-tocopherol contents of the samples (Table 4), and found no significant difference ( 283.40 and $256.65 \mathrm{mg} / \mathrm{kg}$ oil). Saloua et al. (2009) reported 18.92, 10.80, 6.02 and $6.29 \mathrm{mg} / 100 \mathrm{~g}$ oil of $\alpha$-, $\gamma$-, $\beta$-, and $\delta$-tocopherols, respectively. Although we have only measured the $\alpha$-tocopherol content, the $\alpha$-tocopherol contents of our samples are higher than the reported amount. Another study (Matthaus and Özcan, 2012) showed the tocopherol composition of orange seed oil as 9.3 and $0.5 \mathrm{mg} / 100 \mathrm{~g}$ of $\alpha$-, $\gamma$-tocopherol, and $0.2 \mathrm{mg} / 100 \mathrm{~g}$ of $\gamma$-tocotrienol. Again, the $\alpha$-tocopherol contents measured in our samples $(283.40$ and $256.65 \mathrm{mg} / \mathrm{kg})$ are higher than the reported $93 \mathrm{mg} / \mathrm{kg}$ level.

\subsection{Thermal properties of the orange seed oils}

The crystallization and melting onset temperature, peak temperatures and enthalpies of the two orange seed oil samples are shown in Table 5. There is no significant difference between the two samples. Both samples started to crystallize at around $1.53-1.90{ }^{\circ} \mathrm{C}$, and the crystallization peak was reached at around $4.63-5.12{ }^{\circ} \mathrm{C}$, respectively. Since the samples cooled down to $-70{ }^{\circ} \mathrm{C}$ for full crystallization, and then heated gradually, it was possible to observe the melting onset and peak temperatures. The oils started to melt

TABLE 5. Thermal properties of the cold-pressed orange seed oils

\begin{tabular}{|c|c|c|c|c|c|}
\hline & \multicolumn{5}{|c|}{ Orange Seed Oil } \\
\hline & Control & Microwaved Roasted & & Control & Microwaved Roasted \\
\hline Crystallization & & & Melting & & \\
\hline Onset $_{c}\left({ }^{\circ} \mathrm{C}\right)$ & $-1.90 \pm 0.36^{\mathrm{A}}$ & $-1.53 \pm 0.14^{\mathrm{A}}$ & Onset $_{\mathrm{m}}\left({ }^{\circ} \mathrm{C}\right)$ & $-25.79 \pm 0.28^{\mathrm{A}}$ & $-26.16 \pm 0.08^{\mathrm{A}}$ \\
\hline $\mathrm{T}_{\mathrm{c}}\left({ }^{\circ} \mathrm{C}\right)$ & $-5.12 \pm 0.18^{\mathrm{A}}$ & $-4.63 \pm 0.53^{\mathrm{A}}$ & $\mathrm{T}_{\mathrm{m}} 1\left({ }^{\circ} \mathrm{C}\right)$ & $-23.04 \pm 0.41^{\mathrm{A}}$ & $-23.78 \pm 0.18^{\mathrm{A}}$ \\
\hline \multirow[t]{5}{*}{$\Delta \mathrm{H}_{\mathrm{c}}(\mathrm{J} / \mathrm{g})$} & $-30.56 \pm 0.54^{\mathrm{A}}$ & $-31.20 \pm 2.73^{\mathrm{A}}$ & $\mathrm{T}_{\mathrm{m}} 2\left({ }^{\circ} \mathrm{C}\right)$ & $-2.35 \pm 0.06^{\mathrm{A}}$ & $-2.36 \pm 0.17^{\mathrm{A}}$ \\
\hline & & & $\mathrm{T}_{\mathrm{m}} 3\left({ }^{\circ} \mathrm{C}\right)$ & $-0.63 \pm 0.04^{\mathrm{A}}$ & $-0.47 \pm 0.03^{\mathrm{A}}$ \\
\hline & & & $\mathrm{T}_{\mathrm{m}} 4\left({ }^{\circ} \mathrm{C}\right)$ & $5.97 \pm 0.31^{\mathrm{A}}$ & $6.42 \pm 0.28^{\mathrm{A}}$ \\
\hline & & & $\Delta \mathrm{H}_{\mathrm{m}}(\mathrm{J} / \mathrm{g})$ & $56.81 \pm 2.45^{\mathrm{A}}$ & $59.41 \pm 6.05^{\mathrm{A}}$ \\
\hline & & & OIT (min) & $29.51 \pm 5.08^{\mathrm{B}}$ & $44.28 \pm 6.94^{\mathrm{A}}$ \\
\hline
\end{tabular}

\footnotetext{
${ }_{\mathrm{A}, \mathrm{B}}$ means in the same horizontal rows followed by different superscript letters were significantly different $(p<0.05)$.
} 
at around $-26.16-(-25.79){ }^{\circ} \mathrm{C}$, and four different melting peak temperatures were observed at around $-23.78-(-23.04){ }^{\circ} \mathrm{C},-2.36-(-2.35){ }^{\circ} \mathrm{C}$, $-0.47-(-0.63){ }^{\circ} \mathrm{C}$, and $5.97-6.42{ }^{\circ} \mathrm{C}$, respectively. This means that there were four main types of triglyceride forms with distinctly different melting ranges. While crystallization enthalpy was around $30.56-31.20 \mathrm{~J} / \mathrm{g}$, the melting enthalpy was around $56.81-59.41 \mathrm{~J} / \mathrm{g}$. As far as we searched, there is no data in the literature about the thermal properties of orange seed oils; hence, this data would be very useful. Clearly this oil is mostly similar to other unsaturated oils, and stays liquid at refrigerator temperature. This condition could be important in terms of oil storage and transport procedures and preparations of food and other product formulations.

The oxidation induction time (OIT) was also measured (Table 5). The OIT of the microwave roasted sample was higher than the control sample. Accordingly, it could be assumed that there were more antioxidant compounds present in the microwave roasted sample. In fact, it could be observed from Table 3 that the total phenolic content and measured antioxidant capacity value of the microwave roasted sample is higher than that of the control sample. Hence, it might be possible that phenolics and other antioxidant compounds might better leach into the microwave roasted oil. This could be accepted as another benefit of microwave treatment of the seeds prior to cold pressing. There is no data in the literature for orange seed oil to compare, and this data can also be an important contribution.

\section{CONCLUSIONS}

Orange seeds emerge as solid waste from juice processing facilities in large quantities. This study aimed to valorize orange seeds for cold oil production. Furthermore, the meal obtained after oil pressing was analyzed for other possible valorization studies. It was shown that seed microwave roasting prior to cold pressing enhanced oil yield significantly. Likewise, oil turbidity, peroxide value, and antioxidant capacity value were enhanced by microwave roasting. Six different fatty acids quantified in the orange seed oil samples, with the majority of linoleic, palmitic and oleic acids. The fatty acid composition of orange seed oil could be appreciated as very balanced in terms of saturated, monounsaturated and polyunsaturated ratios. While fifteen sterols were quantified, the major one was $\beta$-sitosterol. Microwave roasting had little effect on sterol composition. The thermal parameters of this oil are provided for the first time in the literature, and these data would be helpful during product development applications. Overally, this study showed that orange seed oils could be produced by cold pressing with acceptable yield and good quality to be used in various food, pharmaceutical, chemical and energy industries. Further studies about the applications of this very new oil in different products are suggested.

\section{ACKNOWLEDGMENTS}

This study was funded by the TUBITAK (The Scientific and Technological Research Council of Turkey), Project No: COST 1140876. The authors thank for the fund.

\section{REFERENCES}

Abdel-Rahman AY. 1980. A study on some Egyption citrus seed oils. Grasas Aceites 31, 331-333.

Anwar F, Naseer R, Bhanger MI, Ashraf S, Talpur FN, Aladedunye FA. 2008. Physico-chemical characteristics of citrus seeds and seed oils from Pakistan. J. Am. Oil Chem. Soc. 85, 321-330. http://dx.doi.org/10.1007/ s11746-008-1204-3

AOCS 1997. Official Methods and Recommended Practices Vol I and II. Champaign, Illionis, USA: American Oil Chemists Society.

Aydeniz B, Güneşer O, Yılmaz E. 2014. Physico-chemical, sensory and aromatic properties of cold press produced safflower oil. J. Am. Oil Chem. Soc. 91, 99-110. http://dx.doi. org/10.1007/s11746-013-2355-4

Aydeniz B, Yilmaz E. 2012. Enrichment of frying oils with plant phenolic extracts to extend the usage life. Eur. J. Lipid Sci. Technol. 114, 933-941. http://dx.doi.org/10.1002/ ejlt. 201100228

Azadmard-Damirchi S, Habibi-Nodeh F, Hesari J, Nemati M, Achachouei BF. 2010. Effect of pretreatment with microwaves on oxidative stability and nutraceuticals content of oil from rapeseed. Food Chem. 121, 1211-1215. http:// dx.doi.org/10.1016/j.foodchem.2010.02.006

Codex 2012. Codex for vegetable oils, Number: 2012/29. Ankara, Turkey: Turkish Food Codex.

Doğan D. 2014. Turunçgil zeytin incir ve diğer subtropik meyveler. http://readgur.com/doc/469091/suptropik-meyveler do $\%$ C 4\%9Fan-d o $\%$ C4\% $\%$ Fan---tc-g $\%$ C 4\%B 1 da$\operatorname{tar} \% \mathrm{C} 4 \% \mathrm{~B} 1 \mathrm{~m}-\mathrm{ve}-$ hayvanc. (available at November 2015).

Dündar Emir D, Aydeniz B, Yilmaz E. 2015. Effects of roasting and enzyme pretreatments on yield and quality of coldpressed poppy seed oils. Turk. J. Agric. For. 39, 260-271. http://dx.doi.org/10.3906/tar-1409-34

El-Adawy TA, Rahma EH, El-Bedawy AA, Gafar AM. 1999a. Properties of some citrus seeds. Part 3. Evaluation as a new source of protein and oil. Nahrung 43, 385-391. https://doi. org/10.1002/(SICI)1521-3803(19991201)43:6<385::AIDFOOD 385>3.0.CO;2-V

El-Adawy TA, Rahma EH, El-Bedawy AA, Gafar AM. 1999b. Properties of some citrus seeds. Part 1. Physico-chemical characteristics of proteins. Nahrung 43, 374-378. https://doi. org/10.1002/(SICI)1521-3803(19991201)43:6<374::AIDFOOD 374>3.0.CO;2-2

Grilo Câmara E Costa PN, Gurgel CSS, Beserra AFM, Almeida FNS, Dimenstein R. 2014. Alpha-tocopherol and gamma-tocopherol concentration in vegetable oils. Food Sci. Technol. 34, 379-385. http://dx.doi.org/10.1590/ S0101-20612014005000031

Habib MA, Hammam MA, Sakr AA, Ashoush YA. 1986. Chemical evaluation of Egyptian citrus seeds as potential sources of vegetable oils. J. Am. Oil Chem. Soc. 63, 11921196. http://dx.doi.org/10.1007/BF02663951

ISO 1999. Animal and Vegetable Fats and Oils -Determination of Individual and Total Sterols Contents- Gas Chromatographic Method, ISO 12228:1999. International Standards Official Methods. Geneve, Switzerland: International Organization for Standardization. 
ISO 2000. Animal and vegetable fats and oils -Determination of unsaponifiable matter- Method using diethyl ether extraction, ISO 3596. International Standards Official Methods. Geneve, Switzerland: International Organization for Standardization.

Khoddami A, Che Man YB, Roberts TH. 2014. Physicochemical properties and fatty acid profile of seed oils from pomegranate (Punica granatum L.) extracted by cold pressing. Eur. J. Lipid Sci. Technol. 116, 553-562. http://dx.doi. org/10.1002/ejlt.201300416

Lazos ES, Servos DC. 1988. Nutritional and chemical characteristics of orange seed oil. Grasas Aceites 39, 232-234.

Malacrida CR, Kimura M, Jorge N. 2012. Phytochemicals and antioxidant activity of citrus seed oils. Food Sci. Technol. Res. 18, 399-404. http://doi.org/10.3136/fstr.18.399

Matharu AS, de Melo EM, Houghton JA. 2016. Opportunity for high value-added chemicals from food supply chain wastes. Bioresource Technol. 215, 123-130. http://dx.doi. org/10.1016/j.biortech.2016.03.039

Matthaus B, Özcan MM. 2012. Chemical evaluation of citrus seeds, an agro-industrial waste, as a new potential source of vegetable oils. Grasas Aceites 63, 313-320. https://doi. org/10.3989/gya.118411

Minitab 2010. Minitab Statistical Software (Version 16.1.1). Pennsylvania, USA: Minitab, Inc., State College.

O'Brien RD. 2004. Fats and Oils: Formulating and Processing for Applications. CRC Press, Boca Raton, FL, USA.

Russo M, Bonaccorsi I, Inferrera V, Dugo P, Mondello L. 2015. Underestimated sources of flavonoids, limonoids and dietary fiber: Availability in orange's by-products.
J. Funct. Foods 12, 150-157. http://dx.doi.org/10.1016/j. jff.2014.11.008

Saidani M, DhifiI W, Marzouk B. 2004. Lipid evaluation of some Tunisian citrus seed. J. Food Lipids 11, 242-250. http://dx.doi.org/10.1111/j.1745-4522.2004.01136.x

Saloua F, Eddine NI, Hedi Z. 2009. Chemical composition and profile characteristics of Osage orange Maclura pomifera (Rafin.) Schneider seed and seed oil. industrial crops and products. Ind. Crops Prod. 29, 1-8. http://dx.doi. org/10.1016/j.indcrop.2008.04.013

Statista 2016. Global fruit production in 2013, by variety (in million metric tons) https://www.statista.com/statistics/264001/worldwide-production-of-fruit-by-variety/ (available at October 2016).

SPSS 1994. SPSS Professional Statistics (Version 10,1). Chicago, IL, USA: SPSS Inc.

TUIK 2014. Turunçgiller. http:www.tuik.gov.tr (available at February 2014).

Williams MA, Hron RJ. 1996. Obtaining oils and fats from source materials, in YH Hui (Ed.) Bailey's Industrial Oil and Fat Products. John Wiley \& Sons, Inc., New York, USA, pp. 61-156.

Yilmaz E, Aydeniz B, Güneşer O, Arsunar ES. 2015a. Sensory and physico-chemical properties of cold press produced tomato (Lycopersicon esculentum L.) seed oils. J. Am. Oil Chem. Soc. 92, 833-842. http://dx.doi.org/10.1007/s11746-015-2648-x

Yilmaz E, Öğütcü M, Arifoglu N. 2015b. Assessment of thermal and textural characteristics and consumer preferences of lemon and strawberry flavored fish oil organogels. J. Oleo Sci. 64, 1049-1056. http://dx.doi.org/10.5650/jos.ess15113 